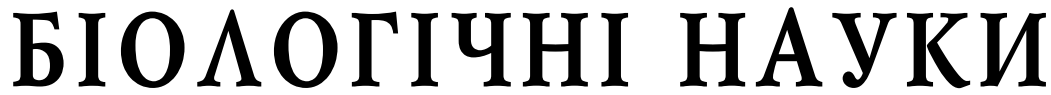

\author{
DOI: https://doi.org/10.32839/2304-5809/2021-11-99-21 \\ УДК 577.1-035.57
}

Осипчук Р.П., Кучменко О.Б.

Ніжинський державний університет імені Миколи Гоголя

\section{БІОХІМІЧНА ХАРАКТЕРИСТИКА АНТИОКСИДАНТНОГО ПОТЕНЦІАЛУ КОРОВ'ЯЧОГО ТА КОЗИНОГО МОЛОКА}

\begin{abstract}
Анотація. У статті досліджено вміст антиоксидантів у нативному та пастеризованому коров'ячому і козиному молоці. Встановлено, що нативне та пастеризоване коров'яче молоко має більш кисле рН порівняно 3 нативним і пастеризованим козиним молоком. Вміст білка в нативному коров'ячому молоці $\epsilon$ меншим порівняно з пастеризованим, а в нативному козиному молоці є більшим порівняно 3 пастеризованим молоком. Активність каталази в нативному коров'ячому молоці є нижчою, а в козиному - вищою порівняно з пастеризованим молоком. Вміст продуктів вільнорадикального перекисного окислення ліпідів, церулоплазміну, вітаміну C, загальних каротиноїдів та SH-груп в нативному коров'ячому та козиному молоці є більшим порівняно з пастеризованим молоком. При цьому зростання вмісту SH-груп в нативно-му коров'ячому молоці відбувається в більшій мірі за рахунок зростання білкових SH-груп, а в козиному переважно за рахунок небілкових SH-груп. Отримані результати вказують на те, що нативне коров’яче та козине молоко слугуе гарним джерелом антиоксидантів для організму людини.
\end{abstract}

Ключові слова: антиоксидантний потенціал, нативне і пастеризоване молоко, церулоплазмін, каталаза, вітамін C, каротиноїди, білок, SH-групи, перекисне окиснення ліпідів.

Osypchuk Ruslan, Kuchmenko Olena Nizhyn Gogol State University

\section{BIOCHEMICAL CHARACTERISTICS OF ANTIOXIDANT POTENTIAL OF COW AND GOAT MILK}

Summary. Due to the rapid deterioration of the ecological state, the level of un-controlled oxidative processes in living cells is increasing. Milk is an integral part of the diet of all populations. The nutritional and biological value of this product is also provided by the antioxidant properties of milk. In addition, they are important indicators of proper nutrition. The study of antioxidant activity of milk in our time is extremely important due to the intensification of oxidation of its various structural components: lipids, carbohydrates, proteins, free structural and functional groups. It is known that antioxidant components of any origin, natural or artificial, slow down or completely inhibit oxidation. Milk has characteristic components of natural origin that play the role of antioxidants, because excessive oxidation leads to rapid spoilage of the product. The article examines the content of antioxidants in native cow's and goat's milk, store-bought cow's and goat's milk. Native and pasteurized cow's milk has been found to have a more acidic $\mathrm{pH}$ than native and pasteurized goat's milk. The protein content of native cow's milk is lower than that of pasteurized milk, and that of native goat's milk is higher than that of pasteurized milk. Catalase activity is lower in native cow's milk and higher in goat's milk compared to pasteurized milk. The content of products of free radical lipid peroxidation, ceruloplasmin, vitamin C, total ca-rotenoids and SH groups in native cow's and goat's milk is higher compared to pasteurized milk. In this case, the increase in the content of SH-groups in native cow's milk is largely due to the growth of protein SH-groups, and in goat - main-ly due to non-protein SH-groups. The results indicate that native cow's and goat's milk is a good source of antioxidants for the human body.

Keywords: antioxidant potential, native milk, store milk, ceruloplasmin, catalase, vitamin C, carotenoids, protein, SH-groups, lipid peroxidation.

Постановка проблеми. В зв’язку зі стрімким погіршенням екологічного стану зростае рівень неконтрольованих окиснювальних процесів у живих клітинах. Молоко є невід'емним компонентом харчування усіх груп населення. Харчова та біологічна цінність цього продукту забезпечуеться також і антиоксидантними властивостями молока. Крім того, вони є важливими показниками повноцінного харчування $[1 ; 2]$. Дослідження антиоксидантної активності молока у наш час набуває надзвичайно важливого значення через інтенсифрікацію процесів окиснення різних його структурних компонентів: ліпідів, вуглеводів, білків, вільних структурно-функціональних груп [1]. Відомо, що антиоксидантні компоненти будь-якого по- ходження, природного чи штучного, сповільнюють або повністю гальмують процеси окиснення. В молоці е характерні компоненти природного походження, що відіграють роль антиоксидантів, адже надмірне окиснення призводить до швидкого псування продукту [1].

Аналіз останніх досліджень і публікацій. Для оцінки стану про- і антиоксидантного балансу в молоці на сьогодні використовують такі показники: вміст продуктів вільнорадикального окислення ліпідів і білків, SH-груп, аскорбінової кислоти, вітамінів $\mathrm{E}, \mathrm{A}$ і $\mathrm{B}_{2}$, активність каталази, супероксидди-смутази, загальна антиоксидантна активність тощо [2-5]. Особливу увагу привертає білок церулоплазмін, який є одним із основних антиоксидантних білків, а також віді- 
грає центральну роль в обміні міді. Крім того, церулоплазмін $е$ білком гострої фрази запалення та стресу. Зростання вмісту церулоплазміну в біологічних рідинах, зокрема і в молоці, може свідчити про розвиток в організмі тварини запального процесу [3].

Ферментні та недерментні компоненти антиоксидантної системи, які містять в молоці, складають основу його природного захисного комплексу, в результаті чого воно володіє антимікробними, імуномодулюючими, протизапальними, протимутагенними властивостями [6].

Виділення невирішених раніше частин загальної проблеми. В разі накопичення в молоці великої кількості продуктів вільнорадикального окислення ліпідів та білків, воно втрачає свої цілющі властивості та може спричиняти розвиток патологічних змін в організмі. Саме це i обумовлюе актуальність даного дослідження, результати якого можуть бути використані в подальшому вивченні корисних властивостей молока та його впливу на живі організми.

Мета статті: дослідити антиоксидантні властивості нативного та пастеризованого коров'ячого і козиного молока.

Виклад основного матеріалу. В якості об’єкту досліджень було взято нативне коров'яче та козине молоко з приватного домогосподарства (м. Коростень, Житомирська область), коров'яче молоко торгової марки «Селянське», козине молоко торгової марки "Girau». Дослідження проводилися у весняний період року. Корови та кози 3 приватного домогосподарства не були вагітні та не вигодували потомство. Нативне коров'яче молоко з приватного домогосподарства було взяте від корів виду Бик Дикий (Bos Taurus L.) із

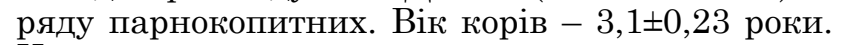
Нативне козине молоко з приватного домогосподарства було взяте від кіз виду Коза Домашня (Carpa hircus L. 1758) iз ряду парнокопитних. Вік кіз - 2,5 $\pm 0,19$ роки. Коров'яче молоко питне ультрапастеризоване торгової марки «Селянське» має 3,2\% жирності (Люстдорфр, Україна). Козине молоко напівзнежирене ультрапастеризоване торгової марки «Girau» має 1,6\% жирності (Arborea, Італія).

У зразках коров'ячого і козиного молока активність каталази визначали за утворенням стійкого комплексу перекису водню з молібдатом амонію спектрофротометрично за методом [10]. Вміст ТБК-позитивних продуктів визначали за утворенням триметинового комплексу альдегідів 3 2-тіобарбітуровою кислотою спектрофротометрично за методом [10]. Вміст церулоплазміну визначали при додаванні p-френілендіаміну фротометрично за методом [11]. Вміст білка визначали за методом Лоурі [12]. Визначення загальних та небілкових SH-груп проводили з використанням розчину кристалічного йоду фотометрично

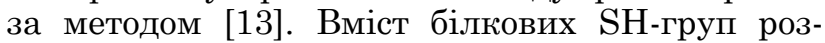
раховували як різницю між вмістом загальних і небілкових SH-груп. Вміст аскорбінової кислоти визначали спектрофотометрично за методом [14]. Вміст загальних каротиноїдів визначали спектрофотометрично за методами [15]. Вимірювання рН молока було проведено з використанням $\mathrm{pH}$-метра $\mathrm{pH}-150 \mathrm{MИ}$ (Білорусь).

Вірогідність отриманих даних встановлювали методами математичної статистики 3 використанням комп'ютерної програми Excel 10. Bci величини змінних відповідали нормальному розподілу. Це дозволило використовувати методи параметричної статистики. При порівнянні значень використовували t-критерій Стьюдента. Всі значення наведені у вигляді $(\mathrm{M} \pm \mathrm{m})(\mathrm{M}-$ середне арифрметичне значення показника, m - стандартна похибка середньої величини). Різниця статистично достовірна при $\mathrm{p} \leq 0,05$.

В результаті проведених досліджень було показано, що всі досліджувані проби молока мають слабо кислу реакщію (табл. 1). Проте слід зазначити, що величина $\mathrm{pH}$ козиного молока, як $з$ приватного домогосподарства, так і торгової марки "Girau», на 0,3 одиниці більша порівняно 3 досліджуваними пробами коров'ячого молока. Внаслідок цього дане молоко може легше засвоюватись організмом людини, оскільки його $\mathrm{pH}$ ближчий до нейтрального [3]. Величина $\mathrm{pH}$ коров'ячого молока більш кисла. Відповідно, засвоєння у кислому середовищі шлунку може відбуватиметься гірше, аніж засвоєння козиного молока.

При вивченні вмісту білка в досліджуваних пробах молока було продемонстровано, що найвищий рівень білка спостерігається у козиному молоці з приватного домогосподарства (табл. 1), який в 2,4 рази більший порівняно 3 козиним молоком торгової марки «Girau». Можливо, це може бути пов'язане 3 технологіями виробництва ультрапастеризованого знежиреного молока. Вміст білку 3 нативному коров'ячому молоці з приватного домогосподарства був на $16,7 \%$ менший порівняно 3 молоком торгової марки "Селянське» (табл. 1). Відповідно, вживаючи в раціон козине молоко, людина забезпечуе себе великою кількістю незамінних амінокислот впродовж тривалого часу [6].

Також в наших дослідженнях продемонстровано, що рівень продуктів перекисного окиснення ліпідів - ТБК-позитивних продуктів в нативному молоці $є$ вищим порівняно 3 пастеризованим. Так, в коров'ячому нативному молоці вміст ТБКпозитивних продуктів є вищим на $82 \%$, а в козиному - в 3,5 рази порівняно 3 пастеризованим (табл. 2). Аналізуючи отримані результати, стає

Величина рН та вміст білка в нативному та пастеризованому

Таблиця 1 коров'ячому та козиному молоці, $M \pm m, n=5$

\begin{tabular}{|l|c|c|}
\hline \multicolumn{1}{|c|}{ Група } & pH & Вміст білка, мг/мл \\
\hline Коров’яче молоко торгової марки «Селянське» & $6,27 \pm 0,06$ & $63,67 \pm 2,03$ \\
\hline Нативне коров’яче молоко з приватного домогосподарства & $6,23 \pm 0,04$ & $53,01 \pm 2,08^{*}$ \\
\hline Козине молоко торгової марки «Girau» & $6,53 \pm 0,05$ & $32,33 \pm 1,45$ \\
\hline Нативне козине молоко з приватного домогосподарства & $6,57 \pm 0,04$ & $78,67 \pm 2,33^{*}$ \\
\hline
\end{tabular}

Примітки: * - різниця достовірна порівняно з пастеризованим молоком відповідної торгової марки $(p \leq 0,05)$. 
Вміст ТБК-позитивних продуктів, активність каталази та вміст церулоплазміну в нативному та пастеризованому коров'ячому та козиному молоці, $\mathbf{M} \pm \mathbf{m}, \mathrm{n}=5$

\begin{tabular}{|l|c|c|c|}
\hline \multicolumn{1}{|c|}{ Група } & $\begin{array}{c}\text { ТБК-позитивні } \\
\text { продукти, мкмоль/л }\end{array}$ & $\begin{array}{c}\text { Активність каталази, } \\
\text { мкмоль/хв на мл }\end{array}$ & $\begin{array}{c}\text { Вміст } \\
\text { церулоплазміну, мг/л }\end{array}$ \\
\hline $\begin{array}{l}\text { Коров'яче молоко торгової } \\
\text { марки «Селянське» }\end{array}$ & $220,09 \pm 7,70$ & $0,038 \pm 0,0016$ & $27,42 \pm 2,28$ \\
\hline $\begin{array}{l}\text { Нативне коров'яче молоко } \\
\text { з приватного домогосподарства }\end{array}$ & $399,57 \pm 9,31^{*}$ & $0,016 \pm 0,0013^{*}$ & $36,46 \pm 1,54^{*}$ \\
\hline $\begin{array}{l}\text { Козине молоко торгової марки } \\
\text { «ігаш» }\end{array}$ & $91,88 \pm 7,70$ & $0,018 \pm 0,0004$ & $13,42 \pm 1,27$ \\
\hline $\begin{array}{l}\text { Нативне козине молоко } \\
\text { з приватного домогосподарства }\end{array}$ & $324,78 \pm 7,71^{*}$ & $0,033 \pm 0,001^{*}$ & $53,96 \pm 2,39^{*}$ \\
\hline
\end{tabular}

Примітки: * - різниця достовірна порівняно з пастеризованим молоком відповідної торгової марки $(p \leq 0,05)$.

очевидним, що рівень продуктів перекисного окислення ліпідів в нативному коров'ячому та козиному молоці є на приблизно одному рівні, в той час як вміст цих продуктів в пастеризованому коров'ячому та козиному молоці суттево відрізняеться (в 2,4 рази).

Ця різниця може бути обумовлена тим, що козине молоко торгової марки «Girau» є знежиреним, тобто містить меншу кількість субстрату до окиснення. Коров'яче молоко торгової марки «Селянське», що досліджувалося, має жирність 3,2\%. Оскільки нативне молоко має більшу жирність, тому це також може бути однією із причин більшого вмісту в ньому продуктів окиснення ліпідів.

Антиоксидантний захист забезпечується фрункціонуванням фрерментної та недерментної ланок антиоксидантної системи [7]. До фрерментної системи антиоксидантного захисту відноситься форемен каталаза (ЕC 1.11.1.6). Так, в наших дослідженнях було продемонстровано, що активність каталази в коров'ячому молоці торгової марки «Селянське» $є$ вищою порівняно 3 нативним коров'ячим молоком в 2,4 рази (табл. 2). На противагу цьому, активність каталази в нативному козиному молоці є вищою порівняно 3 пастеризованим в 1,8 рази (табл. 2). Очевидно, отримані результати активності каталази в пастеризованому молоці можуть бути обумовлені особливостями режиму пастеризащії.

В результаті проведених досліджень було показано, що вміст церулоплазміну в нативному коров'ячому і козиному молоці $є$ вищим порівняно $з$ пастеризованим молоком відповідно на 33\% і в 4 рази (табл. 2). Отримані результати можуть свідчити про більший антиоксидантний потенціал нативного коров'ячого та козиного молока порівняно з пастеризованим. Крім того, нативне молоко може бути гарним джерелом міді для організму. Найнижчий рівень церулоплазміну спостерігається в козиному молоці торгової марки «Girau», що може бути пов'язано з тривалою пастеризацією, задля більшого терміну зберігання, але при менших температурах, близько $55^{\circ} \mathrm{C}$ [8].

Одним із природних антиоксидантів молока та молочних продуктів, які гальмують вільнорадикальне окислення, $є$ сполуки, що містять в своєму складі сульфрідрильні групи. До таких сполук відносяться білки, пептиди та вільні амінокислоти. Ці сполуки виконують антиокислювальну фрункцію за рахунок рухомого атома водню, нейтралізуючи гідроксильні радикали [5]. Казеїн молока має у своєму складі по дві тіолові групи у молекулі $a s 2$-казеїна і $\mathcal{x}$-казеїна, а молекула $\beta$-лактоглобуліна містить одну сульфгідрильну групу. Доступність SH-груп залежить від різних фракторів, таких як фракційний склад білків, ступінь технологічного впливу, виду молочної сировини [5]. В результаті досліджень було продемонстровано, що вміст загальних SH-груп в нативному коров'ячому та козиному молоці $є$ більший порівняно 3 пастеризованим відповідно в 3 і 1,6 рази (табл. 3).

При џьому зростання вмісту SH-груп в нативному коров'ячому молоці відбуваеться в більшій мірі за рахунок зростання білкових $\mathrm{SH}-г р у п ~$ (табл. 3), ніж за рахунок зростання небілкових

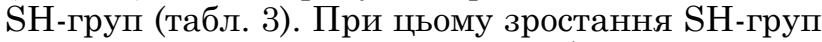
в нативному козиному молоці відбувається за ра-

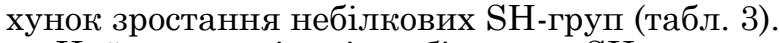

Найменша кількість білкових SH-груп в козиному молоці торгової марки «Girau» узгоджується 3 отриманими даними щодо найменшого

Вміст загальних, білкових та небілкових SH-груп в нативному та пастеризованому коров'ячому та козиному молоці, $\mathrm{M} \pm \mathrm{m}, \mathrm{n}=5$

\begin{tabular}{|l|c|c|c|}
\hline \multicolumn{1}{|c|}{ Група } & $\begin{array}{c}\text { Загальні SH-групи, } \\
\text { ммоль/л }\end{array}$ & $\begin{array}{c}\text { Білкові SH-групи, } \\
\text { ммоль/л }\end{array}$ & $\begin{array}{c}\text { Небілкові SH-групи, } \\
\text { ммоль/л }\end{array}$ \\
\hline $\begin{array}{l}\text { Коров'яче молоко торгової } \\
\text { марки «Селянське» }\end{array}$ & $23,10 \pm 1,63$ & $1,46 \pm 0,77$ & $21,64 \pm 2,40$ \\
\hline $\begin{array}{l}\text { Нативне коров'яче молоко } \\
\text { з приватного домогосподарства }\end{array}$ & $69,01 \pm 2,05^{*}$ & $45,03 \pm 1,46^{*}$ & $23,98 \pm 1,27$ \\
\hline $\begin{array}{l}\text { Козине молоко торгової марки } \\
\text { «інаш» }\end{array}$ & $14,33 \pm 1,78$ & $1,75 \pm 0,51$ & $12,57 \pm 1,27$ \\
\hline $\begin{array}{l}\text { Нативне козине молоко } \\
\text { з приватного домогосподарства }\end{array}$ & $23,10 \pm 1,63^{*}$ & $0,88 \pm 0,51$ & $22,22 \pm 1,27^{*}$ \\
\hline
\end{tabular}

Примітки: * - різниця достовірна порівняно з пастеризованим молоком відповідної торгової марки $(p \leq 0,05)$. 
Вміст аскорбінової кислоти та загальних каротиноїдів в нативному та пастеризованому коров'ячому та козиному молоці, $\mathbf{M} \pm \mathbf{m}, \mathbf{n}=5$

\begin{tabular}{|c|c|c|}
\hline Група & Аскорбінова кислота, моль/л & $\begin{array}{c}\text { Загальні каротиноди, мг \% } \\
\text { (в перерахунку на } \beta \text {-каротин) }\end{array}$ \\
\hline $\begin{array}{l}\text { Коров’яче молоко торгової марки } \\
\text { «Селянське» }\end{array}$ & $0,23 \pm 0,0043$ & $22,67 \pm 4,81$ \\
\hline $\begin{array}{l}\text { Нативне коров'яче молоко } \\
3 \text { приватного домогосподарства }\end{array}$ & $0,27 \pm 0,0045^{*}$ & $77,33 \pm 9,33^{*}$ \\
\hline Козине молоко торгової марки «Girau» & $0,21 \pm 0,003$ & $61,33 \pm 5,81$ \\
\hline $\begin{array}{l}\text { Нативне козине молоко } \\
3 \text { приватного домогосподарства }\end{array}$ & $0,30 \pm 0,016^{*}$ & $126,67 \pm 8,11^{*}$ \\
\hline
\end{tabular}

Примітки: * - різниця достовірна порівняно з пастеризованим молоком відповідної торгової марки ( $p \leq 0,05)$.

вмісту білка в цьому молоці. Зростання вмісту SH-груп в нативному коров'ячому та козиному молоці може свідчити про зростання його антиоксидантного потенщіалу. Так, зростання

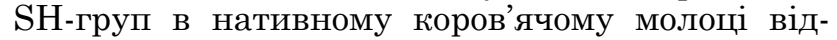
буваеться за рахунок зростання білкових SH-груп, а козиного - за рахунок небілкових SH-груп. При цьому в пастеризованому коров'ячому i козиному молоці домінуючою є фракція небілкових SH-груп, що може бути пов'язане із процесом пастеризації або збагаченням молока екзогенними $\mathrm{SH}$-вмісними сполуками.

Важливий внесок у формування антиоксидантного потенщіалу молока роблять вітаміниантиоксиданти. Так, вміст аскорбінової кислоти в нативному коров'ячому та козиному молоці є більшим порівняно з пастеризованим відповідно на 17\% і 43\% (табл. 4), що можна пояснити можливим руйнуванням аскорбінової кислоти в процесі пастеризації.

Іншою групою сполук 3 антиоксидантними властивостями $е$ каротиноїди, деякі з яких $є$ попередниками вітаміну А в організмі людини і тварин [9]. В результаті проведених досліджень було показано, що в нативному коров'ячому та козиному молоці вміст загальних каротиноїдів $є$ більшим порівняно з пастеризованим молоком відповідно в 3,4 та 2,1 рази (табл. 4). Менший вміст загальних каротиноїдів в пастеризованому молоці може бути обумовлений процесом пастеризації, при якому відбуваеться руйнування каротиноїдів. 3 іншого боку зростання вмісту загальних каротиноїдів в нативному молоці може бути пов'язане як 3 відсутністю його термічної обробки, так і з особливостями харчування тварин, які отримують каротиноїди разом із їжею. Таким чином, нативне коров'яче та козине молоко може слугувати також гарним джерелом вітаміну C та загальних каротиноїдів для людини і тварин.

Висновки і перспективи. В результаті проведених досліджень було продемонстровано, що нативне та пастеризоване коров'яче молоко має більш кисле $\mathrm{pH}$ порівняно 3 нативним і пастеризованим козиним молоком. Вміст білка в нативному коров'ячому молоці є меншим порівняно 3 пастеризованим, а в нативному козиному молоці $є$ більшим порівняно 3 пастеризованим молоком. Вміст продуктів вільнорадикального перекисного окислення ліпідів в нативному коров'ячому та козиному молоці з більшим порівняно $з$ пастеризованим молоком. При цьому активність каталази в нативному коров'ячому молоці є нижчою, а в козиному - вищою порівняно $з$ пастеризованим молоком. Вміст церулоплазміну в нативному коров'ячому та козиному молоці є вищим порівняно з пастеризованим молоком. Вміст SH-груп в нативному коров'ячому та козиному молоці є вищим порівняно з пастеризованим. При цьому зростання вмісту SH-груп в нативному коров'ячому молощі відбуваеться в більшій мірі за рахунок зростання білкових SH-груп, а в козиному - переважно за рахунок небілкових SH-груп. Вміст вітаміну C і загальних каротиноїдів в нативному коров'ячому та козиному молоці є вищим порівняно з пастеризованим молоком.

Підходи до оцінки антиоксидантного статусу молока можна використовувати для оцінки його якості, яка може залежати від характеру харчування тварин, екологічних умов їх перебування, а також від способу переробки, транспортування та умов його зберігання. В перспективі спектр показників, що характеризують про- і антиоксидантний потенщіал молока, може бути розширений.

\section{Список літератури:}

1. Горбатова К. К. Биохимия молока и молочных продуктов. Санкт-Петербург : Гиорд, 2001. 320 с.

2. Spitsberg V. L. Invited reviw: Bovine milk fat globule membrane as a potential nutracelutical. 2005. 2289-2294 p.

3. Веселов П. М. Характеристика антиоксидантных свойств молока из разных әколого-географических подзон лесостепи Омской области. Омск, 2010. 23 с.

4. Лазарева О. Н. Свободорадикальные процесы и антиокислительные свойства молока и кисломолочных продуктов. Уфра, 2008. 23 с.

5. Подольникова Ю. А. Особенности свободорадикального статуса молока коров урбанизированной территории. Омск, 2015. 18 с.

6. Шидловская В. П. Ферменты молока: справочник технолога молочного производства. Санкт-Петербург : ГИОРД. 2006. $296 \mathrm{c.}$

7. Andersen L. W., Thiis J., Kharazmi A., Rygg I. The role of N-acetylcystein administracion on the oxidative response of neutrophils during cardiopulmonary bypass. Perfusion, 1995. 21-26 p.

8. Adam Ambroziak, Pol Merkur Lekarski. Immune stimulative potency of milk proteins. Polish. 2014 . 5-7 p.

9. Kristin M. Hirahatake, Metabolism. Associations between dairy foods, diabetes, and metabolic health: potential mechanisms and future directions. North Am. Pubmed. 2014. 4-7 p. 
10. Барковский Е. В. (и др.). Современные проблемы биохимии. Методы осследований : учеб. пособие / под ред. проф. А.А. Чиркина. Выш. шк. Минск, 2013. 491 с.

11. Камышников В. С. Справочник по клинико-биохимической лабораторной диагностике : В 2 т. Т. 2 . Беларусь. Минск, 2000. 463 с.

12. Белки. Методические указания к лабораторному практикуму. Могилев, 2003. 36 с.

13. Современные методы в биохимии / Под редакцией академика АМН СССР Ореховича В. Н. Медицина. 1977. 391 с.

14. Методы анализа витаминов : Практикум / Сост. Г.Н. Чупахина, П.В. Масленников. Калининград : Изд-во КГУ, 2004. $36 \mathrm{c.}$

15. Sumanta N., Haque C.I., Nishika J., Suprakash R. Spectrophotometric analysis of chlorophylls and carotenoids from commonly grown fern species by using various extracting solvents. Res. J. Chem. Sci. 2014. 4, 63-69.

\section{Referenses:}

1. Horbatova K. K. (2001) Byokhymyia moloka y molochnykh produktov [Biochemistry of milk and dairy products]. Sankt-Peterburh: Hyord, 320 p.

2. Spitsberg V. L. (2005) Invited reviw: Bovine milk fat globule membrane as a potential nutracelutical. $2289-2294 \mathrm{p}$.

3. Veselov P. M. (2010) Kharakterystyka antyoksydantnykh svoistv moloka yz raznykh ekoloho-heohrafycheskykh podzon lesostepy Omskoi oblasty [Characteristics of antioxidant properties of milk from different ecological and geographical subzones of the forest-steppe of the Omsk region]. Omsk, $23 \mathrm{p}$.

4. Lazareva O. N. (2008) Svobodoradykalnye protsesы y antyokyslytelnye svoistva moloka y kyslomolochnykh produktov [Free radical processes and antioxidant properties of milk and fermented milk products]. Ufa, $23 \mathrm{p}$.

5. Podolnykova Yu. A. (2015) Osobennosty svobodoradykalnoho statusa moloka korov urbanyzyrovannoi terrytoryy [Features of the free radical status of milk from cows in an urbanized area]. Omsk, $18 \mathrm{p}$.

6. Shydlovskaia V. P. (2006) Fermenty moloka: spravochnyk tekhnoloha mo-lochnoho proyzvodstva [Milk enzymes: a reference book of a milk production technologist]. Sankt-Peterburh: HYORD, $296 \mathrm{p}$.

7. Andersen L.W., Thiis J., Kharazmi A., Rygg I. (1995) The role of N-acetylcystein administracion on the oxidative response of neutrophils during cardiopulmonary bypass. Perfusion, 21-26 p.

8. Adam Ambroziak, Pol Merkur Lekarski (2014) Immune stimulative potency of milk proteins. Polish. 5-7 p.

9. Kristin M. (2014) Hirahatake, Metabolism. Associations between dairy foods, diabetes, and metabolic health: potential mechanisms and future directions. North Am. Pubmed. 4-7 p.

10. Barkovskyi E. V. (y dr.) (2013) Sovremennye problemy byokhymyy. Metody ossledovanyi: ucheb. Posobye [Modern problems of biochemistry. Research methods: textbook]/ pod red. prof. A.A. Chyrkyna. Vysh. shk. Mynsk, 491 p.

11. Kamyshnykov V. S. (2000) Spravochnyk po klynyko-byokhymycheskoi laboratornoi dyahnostyke [Handbook of clinical and biochemical laboratory diagnostics]: v 2 t., t. 2. Belarus. Mynsk, 463 p.

12. (2003) Belky. Metodycheskye ukazanyia k laboratornomu praktycumu [Proteins. Methodical instructions for laboratory practice]. Mohylev, $36 \mathrm{p}$.

13. (1977) Sovremennye metody v byokhymyy [Modern methods in biochemistry] / Pod redaktsyei akademyka AMN SSSR Orekhovycha V. N. Medytsyna. $391 \mathrm{p}$.

14. (2004) Metody analyza vytamynov [Methods of analysis of vitamins]: Praktykum / Sost. H. N. Chupakhyna, P. V. Maslennykov. Kalynynhrad: Yzd-vo KHU, 36 p.

15. Sumanta N., Haque C.I., Nishika J., Suprakash R. (2014) Spectrophotometric analysis of chlorophylls and carotenoids from commonly grown fern species by using various extracting solvents. Res. J. Chem. Sci., vol. 4, pp. 63-69. 